\title{
Erratum to: The shocking consequences of hybrid epigenomes
}

William T. Jordan and Robert J. Schmitz ${ }^{*}$

\section{Erratum}

After the publication of this work [1] it was noticed that the wrong grant number was acknowledged in the Funding section. The correct grant number is MCB-1339194.

The author apologises for this error.

Received: 18 July 2016 Accepted: 18 July 2016

Published online: 29 July 2016

\section{Reference}

1. Jordan WT, Schmitz RJ. The shocking consequences of hybrid epigenomes. Genome Biol. 2016;17:85.

* Correspondence: schmitz@uga.edu

Department of Genetics, University of Georgia, 120 East Green Street, Athens, GA 30602, USA

\footnotetext{
Submit your next manuscript to BioMed Central and we will help you at every step:

- We accept pre-submission inquiries

- Our selector tool helps you to find the most relevant journal

- We provide round the clock customer support

- Convenient online submission

- Thorough peer review

- Inclusion in PubMed and all major indexing services

- Maximum visibility for your research

Submit your manuscript at

www.biomedcentral.com/submit
} 